\section{Gentle Polish protest}

The Royal Society and the British Academy last week sent a message of "sympathy and support" to the Polish Academy of Sciences. The message, signed by the presidents of the two academies, regrets "the interruption of normal relationships" between Britain and Poland and hopes "that they will soon be resumed". The message is to be sent to other academies which are members of the International Academic Union and the International Council of Scientific Unions.

elected led to nationwide student protests and a virtual shut-down of academic life. At least three rectors have been reported to have been interned: $\mathrm{Dr}$ Henryk Samsonowicz of Warsaw, Dr Jozef Gierowski of the Jagiellonian University of Krakow and chairman of the unofficial rectors' conference and Dr Janusz Ziolkowski of Poznan. How far other rectors will comply with regulations which seem aimed at reducing them simply to disciplinarians is unknown. Vera Rich

\section{Finnish-Soviet research}

\section{Arctic collaboration}

A new Finnish-Soviet Arctic research committee will meet for the first time next month, to work out a new joint programme for the development of the Soviet Arctic. The formation of the committee comes at a critical point in Finnish-Soviet relations: the retirement from politics of President Urno Kekkonen, the chief architect of Finland's policy of neutrality coupled with close economic cooperation with the Soviets.

Earlier this month, Mr Ahti Karjalainen, head of the Bank of Finland and chairman of the Finnish-Soviet economic committee, was in Moscow for talks on future deals including an icebreaker to be built for the Soviets in a Finnish shipyard and a contract, worth up to $£ 125$ million, for the third stage of the paper mills and urban development being built by Finnish expertise at Svetogorsk, just inside the Soviet frontier.

The new Arctic research committee, though essentially a research and development body, will to a certain extent overlap the economic agreements. For example, Mr Karjalainen has been discussing a joint off-shore geological survey for oil and gas in the Barents Sea. Accordingly, one of the major joint research projects on the agenda of the new committee will be devising the technology necessary to construct an oil and gas drilling rig on an ice floe.

Finland has considerable expertise to offer its partner. One participant in the new committee is the University of Oulu, which under the recent policy of decentralized and regionalized higher education runs a programme of research into the economic and development problems of northern Finland, much of which can be immediately applied to work in Arctic Siberia. In particular, Oulu will contribute a new technique for surveying terrain with up to 2 metres of snow cover. Oulu is also the seat of the Research Council for Arctic Medicine, and has a special laboratory for the study of the physiological hazards of work in a cold climate.

The main workload of the cooperation will be undertaken by the Technical Research Centre (Valtion Tekniken Tutkimuskestus, VTT), a governmentsponsored body whose mandate includes research (at cost price) on behalf of those who wish to exploit the results but who do not have the facilities to carry out basic investigations themselves. VTT has 31 laboratories ( 26 in the Helsinki area, 3 in Tampere and 2 in Oulu). Fifteen of these laboratories will be involved in the cooperation programme, and it is estimated that participation will allow VTT to double its research staff in the next few years. Finland, with a population of 4.7 million, has no less than 18 universities, an escalation from two over the past 25 years resulting from "regionalization" policies, and employment for graduates who wish to remain within the Finnish academic/ research structure is a perennial problem. A strong swing of public opinion away from science in the mid-1970s was by no means fully reversed by the then President Kekkonen's call for a reassessment of research and development investments in his New Year message to the nation in 1979. (This was the first time that science had been officially boosted since 1964.)

The new Soviet-Finnish Arctic research programme, the details of which will be worked out next month, is already being regarded by Finnish economists and business experts as a major shot in the arm. Its effect on graduate employment should prove equally beneficial.

Vera Rich

\section{Deep-sea mining}

\section{United States re-think}

\section{Washington}

United States policy on deep-sea mining is again in the melting pot. The recent discovery of large ocean-bed deposits of polymetallic sulphides in various parts of the world has significantly raised the stakes in the continuing disputes over what form of international regulation should be introduced to deep-sea mining.

In the United States, plans are already being discussed to amend the Deep Sea Mining Act, passed by Congress only two years ago. The act provides a mechanism for issuing licences to US companies wishing to collect manganese nodules from the sea bed but could, as it now stands, exclude retrieval of the sulphides.

A different problem exists with the UN Law of the Sea Treaty, negotiations on which are nearing completion after eight years. The current draft of the law is sufficiently flexible to include polymetallic sulphides but US mining companies, backed by the State Department, are concerned that in its present form with no explicit attention to the sulphides, the whole question could be put on hold indefinitely.

Although chemical geologists have long predicted the existence of sulphide deposits associated with rift phenomena on the ocean bed, the first discovery was made as late as 1978 on the sea floor of the East Pacific Rise, near the coast of Mexico. Since then, several similar sites have been discovered off the Pacific coast of the United States, for example in the Juan de Fuca ridge off the state of Oregon. The minerals involved include cobalt, manganese, platinum, zinc and tin.

The most dramatic discovery so far, however, was announced last October by scientists from the National Oceanographic and Atmospheric Administration (NOAA) of the US Department of Commerce. The NOAA geologists have found several mineralized zones between the Galapagos Islands and Ecuador, in the Pacific, which they estimate to contain 25 million tons of polymetallic sulphides. The high concentration of copper and iron in the sulphides is calculated at about 10 per cent each. Also present are lead, molybdenum, vanadium and zinc ( 0.1 per cent each), and silver and tin $(0.3$ per cent), with trace amounts of cadmium, gold and platinum.

Whether the minerals in the sulphide deposits are sufficiently accessible to be worth mining is yet to be determined. The NOAA geologists estimate that the total value of the metals in the latest find is about $\$ 3,000$ million, and new mining and processing technqiues would have to be developed to retrieve them.

Several large companies such as the consortium headed by Lockheed Missiles and Space, are already turning their attention to the commercial potential of the sulphides and are carrying out preliminary exploratory surveys.

Whatever is discovered, mining of the sulphides will inevitably be affected by the negotiations that have taken place within the United Nations since the resources of the high seas were declared, by an unanimous resolution passed in 1970 , to form part of the "common heritage of mankind", whose exploitation should be regulated in a way that would result in the most equitable distribution of benefits.

Deposits relatively close to national coast lines are unlikely to be covered by international legislation. In line with provisions contained in the draft Law of the Sea, the US Congress is expected soon to begin debating a bill which would create a 200-mile exclusive economic zone off the US coast. The discovery of the polymetallic sulphides will add to the political attractions of this bill, since several of the known deposits - such as those in the Juan de Fuca ridge - lie wholly or partially within this distance of the shore. And if the bill passes, as seems likely given the expected support of the Administration, the companies could begin mining the 